\title{
Involvement of advanced glycation end products in the pathogenesis of diabetic complications: the protective role of regular physical activity
}

\author{
P. M. Magalhães • H. J. Appell • J. A. Duarte
}

Received: 30 October 2007 / Accepted: 15 January 2008/Published online: 27 February 2008

(C) EGREPA 2008

\begin{abstract}
Advanced glycation end products (AGEs) may play an important role in the pathogenesis of chronic diabetic complications and in the natural process of biological aging. In fact, maintained hyperglycaemia favours the formation of AGEs at the tissue level in diabetic patients, which may influence the triggering of different chronic pathologies of diabetes such as retinopathy, nephropathy, neuropathy and macro- and micro-vascular diseases. Moreover, the literature has also demonstrated the involvement of AGEs in biological aging, which may explain the accelerated process of aging in diabetic patients. The practice of regular physical activity appears to positively influence glycaemic control, particularly in type 2 diabetes mellitus patients. This occurs through the diminution of fasting glycaemia, with a consequent reduction of glycation of plasmatic components suggested by the normalisation of HbAlc plasmatic levels. This exercise-induced positive effect is evident in the blood of diabetic patients and may also reach the endothelium and connective tissues of different organs, such as the kidneys and eyes, and systems, such as the cardiovascular and nervous systems, with a local reduction of AGEs production and further deceleration of organ dysfunction. The aim of
\end{abstract}

P. M. Magalhães

Polytechnic Institute of Bragança,

Bragança, Portugal

P. M. Magalhães · J. A. Duarte $(\square)$

CIAFEL, Faculty of Sport, University of Porto,

Rua Dr. Plácido Costa, 91,

4200-450 Porto, Portugal

e-mail: jarduarte@fade.up.pt

H. J. Appell

Department of Physiology and Anatomy,

German Sport University,

Cologne, Germany this paper was to review the literature concerning this topic to coherently describe the harmful effects of AGEs in organ dysfunction induced by diabetes in advanced age as well as the mechanisms behind the apparent protection given by the practice of regular physical activity.

Keywords Exercise - Type 2 diabetes mellitus . AGEs $\cdot$ Aging

\section{Introduction}

Regarding its genetic predisposition and clinical specificity, type 2 diabetes mellitus (DM2) represents a heterogeneous pathology, characterised by chronic hyperglycaemia induced by deficient insulin production and/or by a resistance of target tissues to this hormone. DM2 affects approximately $2 \%$ of the world population [2], and the prevalence of this disease is expected to increase to $\sim 50 \%$ by the year 2030 [147].

Prolonged exposure to hyperglycaemia is currently recognised as the first causal factor in the majority of DM2-related late complications [143]. Diabetic patients with poor glycaemic control are particularly at risk for developing associated pathologies described in humans and in animal models, such as cataracts [101], retinopathy, nephropathy, neuropathy [56], micro- and macro-vascular diseases [124], cardiomyopathy [19], and impaired tissue healing [99]. The precise mechanism involved with regard to the role of hyperglycaemia in the pathogenesis of late complications in diabetes is yet to be clarified. Nevertheless, one advanced hypothesis consists of the glycation of proteins, a process which has been widely observed among DM2 patients [35]. In fact, in non-compensated diabetic patients, the blood glucose concentrations are substantially 
augmented. Contrasting with an inadequate glucose utilisation observed in muscle and adipose tissues, cells from other organs that do not need insulin for glucose uptake demonstrate elevated concentrations of glucose at the intracellular level. The high amounts of glucose inside and outside of cells favour the occurrence of spontaneous and non-enzymatic reactions between glucose and proteins in both intra- and extra-cellular compartments [25]. This non-enzymatic glycation of proteins by reducing sugars occurs in a cascade of complex reactions, resulting in a heterogeneous class of components usually classified as advanced glycation end products (AGEs). These types of reactions, initially described by Louis-Camille Maillard in 1912 [81], are strongly associated with hyperglycaemia and tissue oxidative stress [4], and suggestions of their implication in the pathogenesis of chronic complications in diabetes and in aging have increased [129]. On the other hand, the natural process of aging favours the appearance and accumulation of AGEs and of products derived from the process of oxidation, resulting in a vicious cycle that is difficult to stop [74]. There is a wide consensus in the literature that the diminution of the antioxidant capacity is the result of biological aging [64]. However, much evidence supports the concept that regular physical exercise chronically augments the antioxidant capacity [102], which may impair the formation of AGEs in diabetic patients or in individuals in advanced age.

Additionally, the practice of regular physical activity has a positive influence on the glycaemic control, particularly in DM2 patients, through the diminution of fasting glycaemia with the consequent reduction of glucose availability for glycation reactions. Accordingly, regular physical activity may constitute an efficient weapon against DM2-related chronic complications potentially associated with AGEs synthesis.

In this review, we intend to analyse the literature regarding the endogenous and exogenous sources of AGEs, discussing the implication of these products on the aging process and on the late complications of diabetes. Finally, the potential protective role of physical exercise in organ dysfunction induced by AGEs and its underling mechanisms will also be highlighted.

\section{AGEs: endogenous and exogenous sources}

AGEs consist of a complex and heterogeneous group of molecules, whose formation begins with a non-enzymatic reaction between the carbonyl group of reducing sugars with free primary amino groups of amino acids, peptides, and proteins, or with lipids and nucleic acids [99, 110, 144]. This type of reaction is designated by non-enzymatic glycosylation, Maillard's reaction or also, more recently, glycation (Fig. 1).

Amino acids are the structural units of all proteins and are mainly composed of a primary amino group, by a carboxyl group, and by a lateral chain that characterises each amino acid. The linkage between different amino acids is carried out by the reaction between the carboxyl group of one amino acid with the amino group of the following
Fig. 1 Sequence of events responsible for the formation of advanced glycation end products $(A G E s)$. The reaction between glucose molecules and protein amino groups forms the reversible Schiff base that suffers an intramolecular rearrangement, leading to a less reversible Amadori product. In some conditions, these Amadori products form AGEs through a dicarbonyl intermediate such as 3deoxyglucosone. According to Ahmed [2]
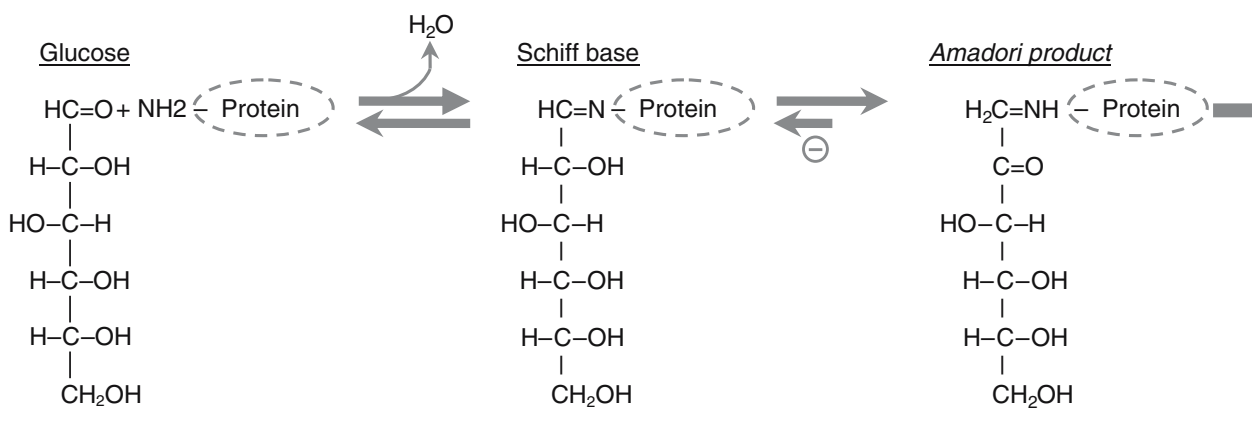
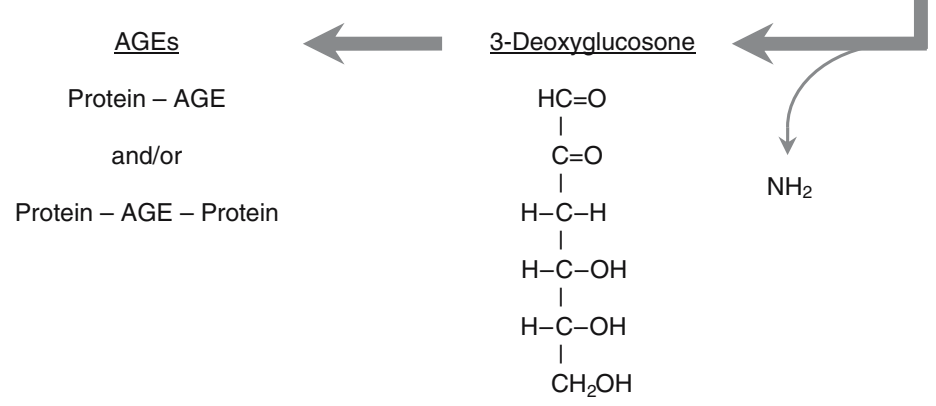
Table 1 Some cross-linking and non-crossed-linking AGEs that have been most often detected in human tissues

\author{
Cross-linking AGEs \\ Pentosidine \\ Crossline \\ Imidazolium dilysine cross-links \\ 1-alkyl-2-formyl-3,4-glycosyl-pyrroles \\ Arginine-lysine imidazole \\ Non-cross-linking AGEs \\ Pyrraline \\ $N \varepsilon$-carboxymethyl-lysine \\ $N \varepsilon$-carboxyethyl-lysine
}

According to Ahmed [2]

amino acid, forming the peptide bond. The establishment of peptide links between different amino acids will create polypeptide chains, within which the primary amino group of the first amino acid, the so-called terminal amino group, is available for further reactions with reducing sugars. Moreover, amino groups belonging to lateral chains of some amino acids, for example lysine and arginine, despite being less reactive than a terminal amino group, may also react with reducing sugars. However, not all the amino groups capable of interacting with sugars actually do so because they can be hidden in the three-dimensional structure of the protein, therefore not permitting access to them [50].

Endogenous glycation reactions occur in a spontaneous way with a small proportion of absorbed simple sugars (glucose, fructose and galactose); the amount of resultant compounds is dependent on the grade and duration of glucose availability, on the body's ability to destroy and excrete them in the urine [95], on the average length of protein life span and on the cellular permeability to free sugars [50]. This type of reaction is carried out in three distinguishable stages (Fig. 1). The initial stage occurs through the association of a sugar with a protein, resulting in a molecular arrangement called the Schiff base. These bases are unstable; therefore, they eventually enter into a process of spontaneous restructuring, with the formation of more stable products such as ketoamine or fructosamine, termed Amadori compounds, among which HbAlc constitutes a good example [5]. The formation of Schiff bases occurs rapidly and reaches thermodynamic equilibrium within a few hours, while in the formation of the Amadori products, the thermodynamic equilibrium is only achieved over a period of a few days [2]. Amadori products have a carbonyl group that can react with other amino groups. The exact mechanism of this reaction is not known in detail, although it is recognised that it involves complex intramolecular rearrangements and, in some cases, the association between several of these compounds. During this second stage, highly reactive compounds are also formed which have two carbonyl groups acting as reaction propagators [8]. In the final stage, a series of slow and complex transformations occurs involving a series of rearrangements, dehydrations and condensations, which lead to the natural formation of generally coloured (brownish yellow) and/or fluorescent compounds, denominated AGEs. In this phase the reactions have an irreversible character, with the formation of crossed links at the intra- and intermolecular levels, and they occur essentially with proteins of low turnover, as is the case for collagen and myelin (Fig. 1) $[141,150]$.

Under physiological conditions, the amount of these compounds is determined by the concentration of reducing sugars and by the length of protein exposition to them. With regard to the proteins of rapid turnover, this glycation process does not normally last beyond the initial stage, namely with the formation of Schiff bases or Amadori products. The main problem lies in the proteins of medium or long life (such as collagen and elastin), which ensure the required time for the AGEs formation and accumulation $[55,138]$. Several types of AGEs observed in human tissues are described in Table 1.

Pentosidine consists of a cross-link between the residues of lysine and arginine (Fig. 2), and its content is augmented in diabetic patients [83]. Crossline, initially described in diabetic mice liver, was observed in in vivo and in vitro studies [94]. The imidazolium dilysine cross-links are formed through the reaction between derivates of glyoxal and residues of lysine [52]. The 1-alkyl-2-formyl-3,4glycosyl-pyrroles are formed through a reaction between two sugars and one unique residue of lysine; their presence is increased in chronic diabetes and they probably contribute to cardiac dysfunction through interaction with type 2 ryanodine receptor calcium-release channels [33]. The arginine-lysine imidazole cross-links were described in Al-Abed and Bucala [7], and it is assumed that they consist of inter-molecular cross-links. Pyrraline is a type of AGE

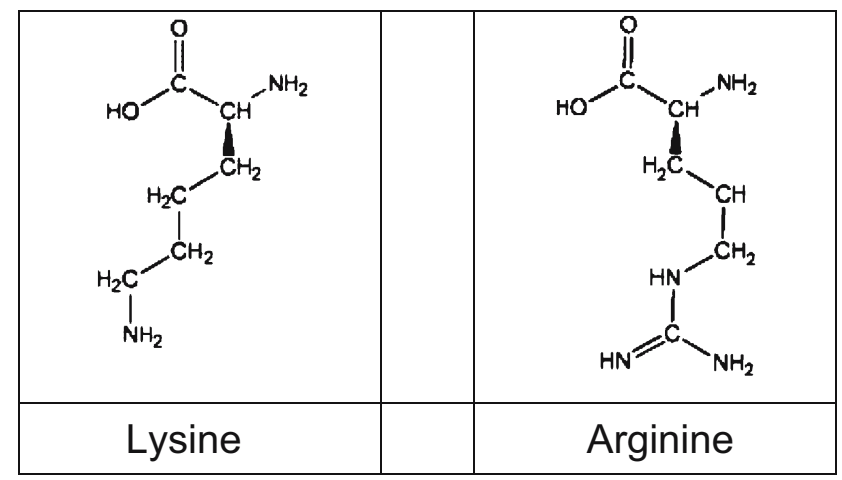

Fig. 2 Chemical structure of lysine and arginine molecules 
without cross-links that has been detected in the skin, in plasma, and in the brain of patients with Alzheimer's disease [121]. $N \varepsilon$-carboximethyl-lysine (CML) is one of the types of AGEs that is most abundant in vivo and whose concentration in collagen tends to be twice as high in diabetic patients as in non-diabetic individuals. Strong correlations with age are also found, being described augmentations up to fivefold from 20 to 85 years of age [48]. They are formed by the oxidative damage of Amadori products and during the oxidation of the methyl group of polyunsaturated fatty acids in the presence of a protein [106].

From the several AGEs species described, CML [61] and pentosidine are the best chemically characterised. The Maillard reaction has been widely used by the food industry due to its implication in the alteration of colour, flavour, aroma and texture of foods [80]. However, it also affects the nutritional properties and toxicity of foods [127]. Additionally, the synthesis of AGEs typically occurs when the sugars are cooked with proteins and/or fats. At temperatures above $120^{\circ} \mathrm{C}\left(\sim 248^{\circ} \mathrm{F}\right)$, an acceleration of protein glycation occurs, but with a longer cooking time at lower temperatures, the formation of AGEs is also promoted. Tobacco can also be a source of AGEs due to the presence of reactive glycated products in its extracts, as well as in the smoke of tobacco in proportions that rapidly react with proteins to form AGEs [34].

A diet rich in AGEs (535 units/mg of CML and $18 \mathrm{nmol} / \mathrm{mg}$ of methylglyoxal (MG) derivatives, during 16 weeks, where food and water intake were recorded daily for 1 week and biweekly thereafter) promoted a 53\% increase of these substances in the serum of mice; on the other hand, a 7.8\% decrease was registered in the low-AGE-diet-mice group (107 units/mg of CML and $3.6 \mathrm{nmol} / \mathrm{mg}$ of MG derivatives during the same time period) [99]. In another study carried out on 26 non-diabetic patients with renal insufficiency, an augmentation of CML (29\%) and derivates of MG (26\%) was also revealed in the blood of the group subjected to an AGE-rich diet, while in the group subjected to a low ingestion of AGEs, a reduction in CML (-34\%) and MG $(-35 \%)$ blood content was observed [137]. These results suggest that a restrictive diet of AGEs could be a reasonable way to reduce excessive overloading of this product in living tissues.

\section{Aging and AGEs formation}

At present, the contribution of the Maillard's reaction to the aging process is well known. The augmentation of these compounds is responsible for the acceleration of cellular aging through the alteration of proteins, lipids, and nucleic acids, through the rise in oxidative stress generated in their formation [74] and also by the interaction with the receptors of the advanced glycation end products (RAGEs) [140]. In recent years, these receptors have been the targets of intense research, and a rising rate of its production has been observed in DM2 patients [16]. It has also been suggested that the actual process of aging favours an increase in the formation of AGEs, essentially in the proteins of the extracellular matrix [3]; its accumulation in the tissues is dependent on time and on the concentration of glucose [25]. Moreover, the occurrence of protein glycation is also associated with the physiopathology of some age-related diseases, such as arthritis, arteriosclerosis, diabetes, and other neurodegenerative pathologies [87].

In another way, the total amount of AGEs has been utilised as a marker of oxidative stress that is experienced daily by the tissues. For instance, Yu and collaborators [150] measured the methionine sulphoxide (MetSO) content in the integumentary collagen of type 1 diabetic patients with and without late complications and in normal individuals. An accumulation of MetSO was observed in the collagen with advanced age. Moreover, this product presented significantly higher values in the diabetic subjects especially when late complications of the disease were present [150]. In another study correlating the AGEs tissue content with aging and diabetes [48], a 33\% increase of fructose-lysine (FL, an initial compound of glycated products) was observed in the collagen fibres with increased age in non-diabetic individuals, as well as augmentations of $500 \%$ in magnitude in CML and in pentosidine, from 20 to 85 years of age. In the same study, diabetic patients evidenced a three-times-greater FL content in the collagen fibres than non-diabetic individuals, which also showed a strong correlation with the levels of glycated haemoglobin. The authors concluded that these chemical alterations in the collagen fibres showed a close association with age, and that glycation reactions were accelerated in diabetes patients. These results support the concept that diabetes is a disease characterised by the acceleration of the degenerative chemical mechanisms associated with biological aging; namely, the disease affects tissue proteins with long life span by the formation of AGEs and by enhanced oxidative stress. The highest AGEs concentrations resulted from both enhanced endogenous synthesis and diet, and can also be directly implicated in the oxidative stress and damage induced on the beta cells of the pancreatic Langerhans islets in diabetic patients [100].

Peripheral resistance to insulin can be the most important factor in triggering DM2, just as it is associated with an increased risk for developing cardiovascular diseases [107]. Many of the molecular mechanisms behind insulin resistance are yet to be determined; however, it is known that they are strongly influenced by age and obesity and, apart from other factors, are dependent on the quantity/quality of 
glucose transporting proteins GLUT4 $[10,30,118]$ and of intracellular insulin receptor substrate-1 (IRS-1) [30]. Several studies associated the formation of the AGEs with the manifestation of peripheral resistance to insulin in adipose tissue [136] and in skeletal muscle [85]. Enhanced cellular oxidative stress is one of the mechanisms suggested to explain insulin resistance, which may be the result of the AGEs binding to RAGEs; the RAGEs stimulation appears to interfere at various levels of the insulin signalling pathway, and it inhibits the translocation of the GLUT4 to the plasma membrane, with a consequent reduction of glucose uptake [111]. Apart from the influences of age, this mechanism also appears to be present in insulin resistance associated with obesity [136] because a reduction in the glucose transport mediated by insulin was recently observed in the adipocytes of older and obese mice [30].

Oxidative stress, generally accepted as a main conditioning factor for the aging process, appears to reduce the pool of GLUT4 available in cells and the GLUT4 signalling mechanism mediated by insulin, thus harming the cellular glucose uptake capacity [89]. Moreover, MG appears to bind directly to IRS-1 inside the muscle fibres, with the direct consequence of an impairment of insulin-induced IRS-1 tyrosine phosphorylation [108]. These data suggest a direct influence of $\mathrm{MG}$ in the induction of insulin resistance, in a way independent of oxidative stress [108].

\section{AGEs and chronic diabetic complications}

Much has been postulated in the literature over the implication of the Maillard reaction in the aging process or in the development of late diabetic complications [50].

Vascular diseases Vascular diseases, particularly cardiac coronary disease, are the principal cause of premature death in diabetic patients. Long-term studies comparing intensive and conventional metabolic control in type 1 [56] and type 2 [135] diabetes mellitus has demonstrated a reduction in the incidence and prevalence of cardiovascular events in well-controlled patients. These data suggest a possible role of hyperglycaemia in the pathology of macro-vascular diseases in diabetes, namely through their influence in the formation of AGEs. These products have already been identified in atherosclerotic plaques, suggesting a possible role of AGEs in the development of cardiovascular diseases in diabetic patients [92]. This assumption is reinforced by the enhanced plasmatic concentrations of AGEs found in DM2 patients with cardiac coronary disease [62]. An association between an increased fluorescence of integumentary collagen and arterial rigidity and elevated systolic and diastolic blood pressures has also been reported in diabetic patients [88]. The diminution of arterial and arteriolar elasticity has been associated with AGEs deposits [120], and it could contribute to the development of systemic hypertension and abnormal shear stress, predisposing the endothelial cells to become damaged and to precocious arteriosclerosis [144]. Additionally, it has been demonstrated in experimental diabetic models that aminoguanidine inhibits the formation of this type of crosslink in collagen fibres within the arterial walls, which reinforces the importance of AGEs in this process [27].

The interaction of AGEs with their cellular surface receptors (RAGEs) has been suggested to have causal implications in the pathogenesis of diabetic vascular complications, stimulating the expression of cellular adhesive molecules in the endothelial cells through the formation of reactive oxygen species (ROS) [15]. During the stimulation of RAGE, an increase in the activation of MAP kinases and of nuclear factor-kappaB (NF-kB) has been observed, as well as the expression of adhesion molecules in vascular cells - the so-called vascular cell adhesion molecule-1 (VCAM-1) [51]. With respect to the cellular surface, the endothelium is stimulated by various mediators, such as endotoxins, $\mathrm{TNF} \alpha$, and AGEs, thus promoting an augmentation in the adhesion of mononuclear proinflammatory cells, at least partly under the influence of the VCAM-1. However, some data [144] suggest that the action of the VCAM-1 is not only limited to cellular adhesion events, but also induces the activation of NADPH endothelial oxidase; this process is essential for the migration of lymphocytes through the stimulated cells. These observations should lead to the assumption that the activation of RAGEs on the cell surface can initiate a cascade of events including the activation of NADPH oxidase and of various pro-inflammatory mediators such as VCAM-1, thus aggravating the generated oxidative stress.

RAGEs were initially identified as specific receptors for AGEs [116]. Nowadays, it is known that they are multibinding receptors, belonging to the super-family of immunoglobulins, which are able to interact with distinct molecules implicated in homeostasis, in inflammatory reactions, and in the development of certain pathologies such as diabetes mellitus and Alzheimer's disease [90]. In diabetic patients, the increased expression of these receptors has been attributed to a wide range of tissues and cells, namely the epithelium, the endothelium, smooth vascular muscle, mononuclear inflammatory cells, the glomerulus and the skin [65]; additionally, AGEs have also been identified in organic fluids of DM2 patients, such as serum and saliva, as well as in skin, confirming an increase in the progression of related complications [53].

The class of S100A12 proteins consists of pro-inflammatory cytokines, mainly expressed by granulocytes, and are involved in the transduction of intercellular signalling events of $\mathrm{Ca} 2+[16]$, with a possible influence in the inflammatory 
process and in autoimmune diseases [76]. The AGEs and the S100/Calgranulins are those which have been most studied as agents of proinflammatory signalling [43, 105] and which appear to trigger intercellular signalling mechanisms that could participate in some of the pathologies associated with diabetes, such as nephropathy [91], retinopathy [14], cardiovascular diseases [68] and loss of bone mass [42].

The treatment of diabetic mice submitted to accelerated arteriosclerosis, through the soluble extra-cellular domain of the RAGE, completely suppressed diabetic atherosclerosis in a glycaemia- and lipid-independent manner [97]. These findings demonstrate that the interaction of the AGEs with their receptors appears to be involved in the development of accelerated arteriosclerosis in diabetes, reinforcing the attention to be paid to these receptors as possible targets with a therapeutic potential for macro- and micro-vascular diseases in diabetes [115].

Diabetic retinopathy Diabetic complications in the retina result from functional and morphological alterations of the local capillaries, such as an increase in the permeability to albumin and other macro-molecules, vascular dysfunction, loss of pericytes, and thickening of the basal membrane. Capillary occlusion is responsible for the local occurrence of impaired blood perfusion (ischaemic retinopathy), which motivates the secretion of vascular endothelial growth factors with the neoformation of veins (proliferative retinopathy) [109].

The role of the AGEs has also been analysed in diabetic mice treated with an AGE inhibitor: Treatment with aminoguanidine, compared to control animals, resulted in a reduction of $75 \%$ in the thickness of the basal membrane of the retinal capillaries [17], in a reduced loss of pericytes [36], in the absence of a development of micro-aneurisms [59] and in the proliferation of endothelial cells [83], in addition to an absence of the accumulation of AGEs in the arterioles [59]. The preventive effect observed in the animal model with an AGE inhibitor, namely through aminoguanidine, lends support to the role of AGEs in the development of the pathophysiological framework for diabetic retinopathy. An increase in vascular permeability was associated in vitro with endothelial endocytosis. An increase in endocytosis in vascular endothelial cells of the retina has been observed with elevated concentrations of glucose, and this could be reduced by aminoguanidine, suggesting also that this alteration is mediated by the AGEs [125].

Diabetic nephropathy Diabetic nephropathy is predominantly characterised by the abnormal depositing of proteins in the glomerular mesangial space, such as type IV and type $\mathrm{V}$ collagen, laminin and fibronectin, leading to its expan- sion and, consequently, to the progressive occlusion of capillaries with consequent renal dysfunction. Two predominant mechanisms should be considered in this process, namely the enlargement of cells and the expansion of the mesangial matrix; the latter is apparently a determinant factor in the progression of renal disease associated with diabetes [123]. Various authors have described a direct relationship between levels of hyperglycaemia and the lesions observed in diabetic nephropathy, principally in the expansion of the mesangial matrix (e.g., $[12,13])$. On the other hand, a close relationship has also been shown between serum and tissue levels of AGEs and the occurrence of functional renal alterations [130], with an increased amount of these products in the mesangium and in the glomerular basal membranes of diabetic patients. CML seems to be the most abundant AGE type in the mesangium (96\%), in the glomerular basal membranes $(42 \%)$, in the tubular basal membranes $(85 \%)$ and in the vein walls $(96 \%)$. Pentosidine appears to be preferentially localised in the interstitial collagen (90\%) and, in comparison to CML, presents a less consistent concentration in the mesangium $(77 \%)$, in the glomerular basal membranes (4\%) and in the tubular basal membranes (31\%) [131]. The presence of these compounds in renal structures may contribute to the tissue lesions described in diabetes, thus altering the architecture of the extra-cellular matrix through glycation reactions with the formation of protein cross links $[28,123]$. Another mechanism that appears to participate in the pathogenesis of nephropathy is also mediated by the AGEs through their interaction with the RAGEs [148], as well as by the deregulation of these receptors, particularly at the podocytes [57]. Indeed, a direct relationship between serum levels of circulating RAGEs and AGEs and the severity of the nephropathy in DM2 patients has been established [130]. In another longitudinal study performed with type 1 diabetic patients followed up over 2.5 years, the predictive value of AGE serum levels for the development of morphological alterations in the kidneys was highlighted [18].

Diabetic neuropathy Peripheral and autonomic neuropathies are the most frequent manifestations of diabetic neuropathy, both as independent predictors of ulcerations and amputations of the lower limb, and they are related to the mortality associated with diabetes [49]. Diabetic neuropathy increases with age and with the evolution of the disease and is present in more than $50 \%$ of DM2 patients older than 60 years of age [149]. An increased skin auto-fluorescence has been described in diabetes, which is directly correlated with the severity of peripheral and autonomic nervous dysfunction, with the patient's age, with the time period of the disease, with average HbA1c levels over the preceding years and with the occurrence of 
ulcerations of the lower limbs [84]. These observations suggest that the determination of AGEs in the skin by autofluorescence may constitute an important tool for the early diagnosis of diabetic neuropathy. From the several chronic complications of diabetes, neuropathic physiopathology has been the most difficult to be associated with AGEs.

Various studies suggest that the irreversible glycation of the cytoskeletal proteins in axons of peripheral nerves is responsible for the formation of cross-links and for the occurrence of functional alterations in neurons, especially axonal degeneration $[86,112,113]$. Other authors also propose the contribution of peripheral arterial occlusion to this process, and this link is supported by the similar pattern distribution between the areas showing ischaemia and neuropathic alterations $[26,146]$. Irreversible links between AGEs and the myelin proteins have also been described, which appear to contribute to the process of segmental demyelination observed in the peripheral nerves of diabetic patients and of aged subjects [141]. The phagocytosis of glycated myelin by macrophages was described in vitro, leading to the assumption that these cells are also able to secrete proteases to the extra-cellular medium, which may further contribute to the nerve demyelination observed in diabetic neuropathy [142]. This demyelination and axonal degeneration should explain the diminution in the speed of sensible and motor nervous conduction in the peripheral nerves associated with diabetes and aging [70]. In fact, diabetic patients followed up over 8 years showed a reduction of $1.3 \mathrm{~m} / \mathrm{s}$ in the speed of nervous impulse conduction in the peroneal, posterior tibial and sural nerves when the HbA1 levels increased by $1 \%$ [9]. Additionally, the interaction between AGEs and RAGEs seems to activate the transcription factor NF- $\mathrm{KB}$ in the microvascular environment [21], which plays a central role in sensorial neural dysfunction and, therefore, might contribute to the physiopathology of diabetic neuropathy [20].

\section{AGEs and regular physical activity}

Several publications report the beneficial effects of lifestyle intervention programmes on DM2 prevention [77, 133], as well as on the improvement of glycaemic control, with a consequent delay of chronic complications in diabetic patients $[23,75]$. In these patients, the simple diminution of $1 \%$ in $\mathrm{HbA} 1 \mathrm{c}$ has reduced the overall risk of death by $21 \%$, of fatal and non-fatal myocardial infarction events by $14 \%$, of fatal and non-fatal cardiac arrests by $12 \%$, of micro-vascular complications by $37 \%$, of required cataract surgeries by $19 \%$, of the number of amputations by $43 \%$ and of cardiac insufficiency incidents by $16 \%$ [128].
The practice of regular physical activity has displayed a positive relationship with the improvement of glycaemic control in patients with DM2 through the diminution of fasting glycaemia $[41,72,132]$ and HbA1c $[22,31,41,45$, $72,82,132,139]$. However, some authors were unable to observe this association [117], which could be explained by the different methodology used (questionnaires) to determine physical activity levels.

In spite of the number of works analysing the control of glycaemia through regular physical activity $[23,24,29,31$, $32,45-47,60,72,73,78,79,82,119,132,152]$, very few have focused on the effects of physical activity on the formation of AGEs in diabetic patients and/or during aging [96, 98]. It can nevertheless be assumed that regular physical activity, as an integrated part of an active lifestyle, may influence the accumulation of AGEs in the organism because the amount of these compounds is conditioned by glycaemia levels [58]. Therefore, the improvements of glycaemic control in DM2 due to physical exercise, usually linked with the reduction of the peripheral resistance to insulin $[37,72,132]$, could attenuate the formation and accumulation of AGEs in the tissue.

However, because of its irreversible character, a significant diminution of AGEs affecting tissue proteins of low turnover, such as collagen [11, 122], elastin [69, 122] and myelin $[66,112]$, cannot be predicted. Regarding oxidative stress, it is assumed that regular physical activity contributes to an augmentation of the antioxidant capacity, facilitating a more efficient combat against the formation of ROS [39, 71, $72,104]$. However, when a subject is unaccustomed to exercise or when it is practised too intensively, it can induce considerable oxidative stress and damage to the exercised muscles, affecting capillaries, muscle fibres and connective tissue [44].

In a recent study, a reduction in the antioxidant enzyme capacity was observed in red blood cells of diabetic mice, showing a negative correlation with hyperglycaemia, and was attenuated by the administration of aminoguanidine [126]. Some authors argue that AGE formation may contribute to the antioxidant diminution observed in uncompensated diabetes, where the loss of glucose homeostasis, with the consequent glycation of antioxidant enzymes such as catalase, glutathione peroxidase, glutathione reductase and reduced glutathione, may attenuate their activity [1, 114]. The hyper-production of free radicals during unbalanced diabetes also appears to interfere at the level of endothelial dysfunction by the reduction of nitric oxide production, leading to impairment in vasodilatation by smooth muscle cells [144]. On the other hand, the AGEs can also increase the susceptibility to LDL oxidation, which will diminish the production of endothelial nitric oxide [28]. Therefore, the association between oxidative stress and AGEs may explain, at least in part, the close relationship between hyper- 
glycaemia, endothelial dysfunction, and tissue damage, namely through the observation of correlations between microvascular lesions and the accumulation of AGEs in diabetic patients with retinopathy and nephropathy [145]. It has also been observed that the formation of AGEs can be retarded or attenuated, but not completely abolished, through an efficient glycaemic control [134]. In this sense, the option of the regular practice of physical activity could be one interesting approach to controlling glycaemia through the reduction of peripheral resistance to insulin, attenuating the formation of AGEs, as well as associated oxidative stress $[24,45]$. Moreover, the enhancement of the antioxidant enzymatic capacity [63], the improvement of vasodilatation capacity of blood vessels [38] and the favourable modifications of lipoprotein blood profile $[6,32]$ and the increment of LDL oxidation resistance [150] have also been described as favourable adaptations of diabetic patients taking part in physical exercise programmes. All these advantages may also be complemented by the improvement in the profile of inflammatory markers induced by physical exercise in diabetic patients, namely a diminution of the C-reactive protein [54, 67, 103], IL-1 [54], IL-6 [40, 54, 67], IL-8 [93], IL-18 [67], tumour necrosis factor- $\alpha$ [67], interferon $\gamma$ [54] and ICAM-1 [151] and an increase in IL-10 [54].

There appears to be a scarcity of studies which have looked at the effects of regular physical exercise on AGE formation, analysing not only the regularity and intensity of this exercise but also the aspects related to its interaction with exogenous sources of those compounds. However, the existing body of literature on this topic allows speculation that the implementation of structured and controlled programmes designed to increase the levels of regular physical activity among DM2 patients, in conjunction with a hypo-calorific diet poor in AGEs, would be fundamental for diminishing the risk of early triggering of chronic diabetic complications and for increasing their physical, psychological and social well being. It is, however, necessary to consider the real impact of the implementation of physical exercise programmes, especially among the population of advanced age with inherent physical limitations where these programmes may exaggerate the acute stress normally induced by physical exercise. Indeed, some evidence [1] has reinforced the concept of the lower capacity of diabetic patients to tolerate elevated levels of physical activity, partially due to their greater vulnerability to the oxidative stress and damage.

\section{References}

1. Abou-Seif MA, Youssef AA (2004) Evaluation of some biochemical changes in diabetic patients. Clin Chim Acta 346:161-170
2. Ahmed N (2005) Advanced glycation endproducts - role in pathology of diabetic complications. Diabetes Res Clin Pract 67:3-21

3. Ahmed N, Ahmed U, Thornalley PJ, Hager K, Fleischer G, Munch G (2005) Protein glycation, oxidation and nitration adduct residues and free adducts of cerebrospinal fluid in Alzheimer's disease and link to cognitive impairment. J Neurochem 92:255-263

4. Ahmed N, Babaei-Jadidi R, Howell SK, Beisswenger PJ, Thornalley PJ (2005) Degradation products of proteins damaged by glycation, oxidation and nitration in clinical type 1 diabetes. Diabetologia 48:1590-1603

5. Ahmed N, Thornalley PJ (2003) Quantitative screening of protein biomarkers of early glycation, advanced glycation, oxidation and nitrosation in cellular and extracellular proteins by tandem mass spectrometry multiple reaction monitoring. Biochem Soc Trans 31:1417-1422

6. Ainslie PN, Reilly T, Maclaren DP, Campbell IT (2005) Changes in plasma lipids and lipoproteins following 10-days of prolonged walking: influence of age and relationship to physical activity level. Ergonomics 48:1352-1364

7. Al-Abed Y, Bucala R (2000) Structure of a synthetic glucose derived advanced glycation end product that is immunologically cross-reactive with its naturally occurring counterparts. Bioconjug Chem 11:39-45

8. Al-Abed Y, Mitsuhashi T, Li H, Lawson JA, FitzGerald GA, Founds H, Donnelly T, Cerami A, Ulrich P, Bucala R (1999) Inhibition of advanced glycation endproduct formation by acetaldehyde: role in the cardioprotective effect of ethanol. Proc Natl Acad Sci U S A 96:2385-2390

9. Amthor KF, Dahl-Jorgensen K, Berg TJ, Heier MS, Sandvik L, Aagenaes O, Hanssen KF (1994) The effect of 8 years of strict glycaemic control on peripheral nerve function in IDDM patients: the Oslo Study. Diabetologia 37:579-584

10. Armoni M, Harel C, Burvin R, Karnieli E (1995) Modulation of the activity of glucose transporters (GLUT) in the aged/obese rat adipocyte: suppressed function, but enhanced intrinsic activity of GLUT. Endocrinology 136:3292-3298

11. Avery NC, Bailey AJ (2005) Enzymic and non-enzymic crosslinking mechanisms in relation to turnover of collagen: relevance to aging and exercise. Scand J Med Sci Sports 15:231-240

12. Bangstad HJ, Osterby R, Dahl-Jorgensen K, Berg KJ, Hartmann A, Hanssen KF (1994) Improvement of blood glucose control in IDDM patients retards the progression of morphological changes in early diabetic nephropathy. Diabetologia 37:483-490

13. Barbosa J, Steffes MW, Sutherland DE, Connett JE, Rao KV, Mauer SM (1994) Effect of glycemic control on early diabetic renal lesions. A 5-year randomized controlled clinical trial of insulin-dependent diabetic kidney transplant recipients. JAMA 272:600-606

14. Barile GR, Pachydaki SI, Tari SR, Lee SE, Donmoyer CM, Ma W, Rong LL, Buciarelli LG, Wendt T, Horig H, Hudson BI, Qu W, Weinberg AD, Yan SF, Schmidt AM (2005) The RAGE axis in early diabetic retinopathy. Invest Ophthalmol Vis Sci 46:2916-2924

15. Basta G, Lazzerini G, Massaro M, Simoncini T, Tanganelli P, Fu C, Kislinger T, Stern DM, Schmidt AM, De Caterina R (2002) Advanced glycation end products activate endothelium through signal-transduction receptor RAGE: a mechanism for amplification of inflammatory responses. Circulation 105:816-822

16. Basta G, Sironi AM, Lazzerini G, Del Turco S, Buzzigoli E, Casolaro A, Natali A, Ferrannini E, Gastaldelli A (2006) Circulating soluble receptor for advanced glycation end-products (sRAGE) is inversely associated with glycemic control and S100A12 protein. J Clin Endocrinol Metab 91:4628-4634

17. Beisswenger PJ, Moore LL, Brinck-Johnsen T, Curphey TJ (1993) Increased collagen-linked pentosidine levels and 
advanced glycosylation end products in early diabetic nephropathy. J Clin Invest 92:212-217

18. Berg TJ, Bangstad HJ, Torjesen PA, Osterby R, Bucala R, Hanssen KF (1997) Advanced glycation end products in serum predict changes in the kidney morphology of patients with insulin-dependent diabetes mellitus. Metabolism 46:661-665

19. Bidasee KR, Nallani K, Yu Y, Cocklin RR, Zhang Y, Wang M, Dincer UD, Besch HR (2003) Chronic diabetes increases advanced glycation end products on cardiac ryanodine receptors/ calcium-release channels. Diabetes 52:1825-1836

20. Bierhaus A, Haslbeck KM, Humpert PM, Liliensiek B, Dehmer T, Morcos M, Sayed AA, Andrassy M, Schiekofer S, Schneider JG, Schulz JB, Heuss D, Neundorfer B, Dierl S, Huber J, Tritschler H, Schmidt AM, Schwaninger M, Haering HU, Schleicher E, Kasper M, Stern DM, Arnold B, Nawroth PP (2004) Loss of pain perception in diabetes is dependent on a receptor of the immunoglobulin superfamily. J Clin Invest 114:1741-1751

21. Bierhaus A, Schiekofer S, Schwaninger M, Andrassy M, Humpert PM, Chen J, Hong M, Luther T, Henle T, Kloting I, Morcos M, Hofmann M, Tritschler H, Weigle B, Kasper M, Smith M, Perry G, Schmidt AM, Stern DM, Haring HU, Schleicher E, Nawroth PP (2001) Diabetes-associated sustained activation of the transcription factor nuclear factor-kappaB. Diabetes 50:2792-2808

22. Bjorgaas M, Vik JT, Saeterhaug A, Langlo L, Sakshaug T, Mohus RM, Grill V (2005) Relationship between pedometerregistered activity, aerobic capacity and self-reported activity and fitness in patients with type 2 diabetes. Diabetes Obes Metab 7:737-744

23. Boule NG, Haddad E, Kenny GP, Wells GA, Sigal RJ (2001) Effects of exercise on glycemic control and body mass in type 2 diabetes mellitus: a meta-analysis of controlled clinical trials. JAMA 286:1218-1227

24. Brooks N, Layne JE, Gordon PL, Roubenoff R, Nelson ME, Castaneda-Sceppa C (2006) Strength training improves muscle quality and insulin sensitivity in Hispanic older adults with type 2 diabetes. Int J Med Sci 4:19-27

25. Brownlee M (1995) Advanced protein glycosylation in diabetes and aging. Annu Rev Med 46:223-234

26. Brownlee M, Vlassara H, Cerami A (1986) Trapped immunoglobulins on peripheral nerve myelin from patients with diabetes mellitus. Diabetes 35:999-1003

27. Brownlee M, Vlassara H, Kooney A, Ulrich P, Cerami A (1986) Aminoguanidine prevents diabetes-induced arterial wall protein cross-linking. Science 232:1629-1632

28. Bucala R, Vlassara H (1995) Advanced glycosylation end products in diabetic renal and vascular disease. Am J Kidney Dis 26:875-888

29. Cardoso SS, Feuers RJ, Tsai TH, Hunter JD, Scheving LE (1990) Chronobiology of exercise: the influence of scheduling upon glycemic responses of control and of subjects with diabetes mellitus. Prog Clin Biol Res 341B:345-353

30. Carvalho E, Rondinone C, Smith U (2000) Insulin resistance in fat cells from obese Zucker rats - evidence for an impaired activation and translocation of protein kinase $\mathrm{B}$ and glucose transporter 4. Mol Cell Biochem 206:7-16

31. Castaneda C, Layne JE, Munoz-Orians L, Gordon PL, Walsmith J, Foldvari M, Roubenoff R, Tucker KL, Nelson ME (2002) A randomized controlled trial of resistance exercise training to improve glycemic control in older adults with type 2 diabetes. Diabetes Care 25:2335-2341

32. Cauza E, Hanusch-Enserer U, Strasser B, Kostner K, Dunky A, Haber P (2006) The metabolic effects of long term exercise in Type 2 Diabetes patients. Wien Med Wochenschr 156:515-519

33. Cerami A, Vlassara H, Brownlee M (1988) Role of advanced glycosylation products in complications of diabetes. Diabetes Care 11(Suppl 1):73-79
34. Cerami C, Founds H, Nicholl I, Mitsuhashi T, Giordano D, Vanpatten S, Lee A, Al-Abed Y, Vlassara H, Bucala R, Cerami A (1997) Tobacco smoke is a source of toxic reactive glycation products. Proc Natl Acad Sci U S A 94:13915-13920

35. Ceriello A (1999) Hyperglycaemia: the bridge between nonenzymatic glycation and oxidative stress in the pathogenesis of diabetic complications. Diabetes Nutr Metab 12:42-46

36. Chibber R, Molinatti PA, Wong JS, Mirlees D, Kohner EM (1994) The effect of aminoguanidine and tolrestat on glucose toxicity in bovine retinal capillary pericytes. Diabetes 43: 758-763

37. Cuff DJ, Meneilly GS, Martin A, Ignaszewski A, Tildesley HD, Frohlich JJ (2003) Effective exercise modality to reduce insulin resistance in women with type 2 diabetes. Diabetes Care 26:2977-2982

38. De Filippis E, Cusi K, Ocampo G, Berria R, Buck S, Consoli A, Mandarino LJ (2006) Exercise-induced improvement in vasodilatory function accompanies increased insulin sensitivity in obesity and type 2 diabetes mellitus. J Clin Endocrinol Metab 91:4903-4910

39. Dekany M, Nemeskeri V, Gyore I, Harbula I, Malomsoki J, Pucsok J (2006) Antioxidant status of interval-trained athletes in various sports. Int J Sports Med 27:112-116

40. Dekker MJ, Lee S, Hudson R, Kilpatrick K, Graham TE, Ross R, Robinson LE (2007) An exercise intervention without weight loss decreases circulating interleukin-6 in lean and obese men with and without type 2 diabetes mellitus. Metabolism 56:332-338

41. Di Loreto C, Fanelli C, Lucidi P, Murdolo G, De Cicco A, Parlanti N, Ranchelli A, Fatone C, Taglioni C, Santeusanio F, De Feo P (2005) Make your diabetic patients walk: long-term impact of different amounts of physical activity on type 2 diabetes. Diabetes Care 28:1295-1302

42. Ding KH, Wang ZZ, Hamrick MW, Deng ZB, Zhou L, Kang B, Yan SL, She JX, Stern DM, Isales CM, Mi QS (2006) Disordered osteoclast formation in RAGE-deficient mouse establishes an essential role for RAGE in diabetes related bone loss. Biochem Biophys Res Commun 340:1091-1097

43. Ding Y, Kantarci A, Hasturk H, Trackman PC, Malabanan A, Van Dyke TE (2007) Activation of RAGE induces elevated O2generation by mononuclear phagocytes in diabetes. J Leukoc Biol 81:520-527

44. Duarte JA, Appell HJ, Carvalho F, Bastos ML, Soares JM (1993) Endothelium-derived oxidative stress may contribute to exerciseinduced muscle damage. Int J Sports Med 14:440-443

45. Dunstan DW, Daly RM, Owen N, Jolley D, De Courten M, Shaw J, Zimmet P (2002) High-intensity resistance training improves glycemic control in older patients with type 2 diabetes. Diabetes Care 25:1729-1736

46. Dunstan DW, Mori TA, Puddey IB, Beilin LJ, Burke V, Morton AR, Stanton KG (1997) The independent and combined effects of aerobic exercise and dietary fish intake on serum lipids and glycemic control in NIDDM. A randomized controlled study. Diabetes Care 20:913-921

47. Dunstan DW, Vulikh E, Owen N, Jolley D, Shaw J, Zimmet P (2006) Community center-based resistance training for the maintenance of glycemic control in adults with type 2 diabetes. Diabetes Care 29:2586-2591

48. Dyer DG, Dunn JA, Thorpe SR, Bailie KE, Lyons TJ, McCance DR, Baynes JW (1993) Accumulation of Maillard reaction products in skin collagen in diabetes and aging. $\mathrm{J}$ Clin Invest 91:2463-2469

49. Ewing DJ, Campbell IW, Clarke BF (1976) Mortality in diabetic autonomic neuropathy. Lancet 1:601-603

50. Flecha LG, Castello PR, Gagliardino JJ, Rossi JP (2000) La glucosilación no enzimática de proteínas. Mecanismo y papel de la reacción en la diabetes y el envejecimiento. Cienc Día Int 3: $1-17$ 
51. Fodor JG, Adamo KB (2001) Prevention of type 2 diabetes mellitus by changes in lifestyle. N Engl J Med 345:696 author reply $696-697$

52. Frye EB, Degenhardt TP, Thorpe SR, Baynes JW (1998) Role of the Maillard reaction in aging of tissue proteins. Advanced glycation end product-dependent increase in imidazolium crosslinks in human lens proteins. J Biol Chem 273:18714-18719

53. Garay-Sevilla ME, Regalado JC, Malacara JM, Nava LE, Wrobel-Zasada K, Castro-Rivas A, Wrobel K (2005) Advanced glycosylation end products in skin, serum, saliva and urine and its association with complications of patients with type 2 diabetes mellitus. J Endocrinol Invest 28:223-230

54. Goldhammera E, Tanchilevitcha A, Maorb I, Beniaminia Y, Rosenscheina U, Sagive M (2005) Exercise training modulates cytokines activity in coronary heart disease patients. Int J Cardiol 100:93-99

55. Greenwald SE (2007) Ageing of the conduit arteries. J Pathol 211:157-172

56. The Diabetes Control and Complications Trial Research Group (1993) The effect of intensive treatment of diabetes on the development and progression of long-term complications in insulin-dependent diabetes mellitus. The Diabetes Control and Complications Trial Research Group. N Engl J Med 329:977-986

57. Gu L, Hagiwara S, Fan Q, Tanimoto M, Kobata M, Yamashita M, Nishitani T, Gohda T, Ni Z, Qian J, Horikoshi S, Tomino Y (2006) Role of receptor for advanced glycation end-products and signalling events in advanced glycation end-product-induced monocyte chemoattractant protein-1 expression in differentiated mouse podocytes. Nephrol Dial Transplant 21:299-313

58. Hammes H-P, Wellensiek B, Kloting I, Sickel E, Bretzel R, Brownlee M (1998) The relationship of glycaemic level to advanced glycation end-product (AGE) accumulation and retinal pathology in the spontaneous diabetic hamster. Diabetologia $41: 165-170$

59. Hammes HP, Martin S, Federlin K, Geisen K, Brownlee M (1991) Aminoguanidine treatment inhibits the development of experimental diabetic retinopathy. Proc Natl Acad Sci U S A 88:11555-11558

60. Heath GW, Wilson RH, Smith J, Leonard BE (1991) Communitybased exercise and weight control: diabetes risk reduction and glycemic control in Zuni Indians. Am J Clin Nutr 53:1642S$1646 \mathrm{~S}$

61. Ikeda K, Higashi T, Sano H, Jinnouchi Y, Yoshida M, Araki T, Ueda S, Horiuchi S (1996) N (epsilon)-(carboxymethyl)lysine protein adduct is a major immunological epitope in proteins modified with advanced glycation end products of the Maillard reaction. Biochemistry 35:8075-8083

62. Kilhovd BK, Berg TJ, Birkeland KI, Thorsby P, Hanssen KF (1999) Serum levels of advanced glycation end products are increased in patients with type 2 diabetes and coronary heart disease. Diabetes Care 22:1543-1548

63. Kim JD, McCarter RJ, Yu BP (1996) Influence of age, exercise, and dietary restriction on oxidative stress in rats. Aging (Milano) 8:123-129

64. Kim JW, No JK, Ikeno Y, Yu BP, Choi JS, Yokozawa T, Chung HY (2002) Age-related changes in redox status of rat serum. Arch Gerontol Geriatr 34:9-17

65. Kim W, Hudson BI, Moser B, Guo J, Rong LL, Lu YAN, Qu WU, Lalla E, Lerner S, Chen Y, Yan SSD, D'Agati V, Naka Y, Ramasamy R, Herold K, Yan SF, Schmidt AM (2005) Receptor for advanced glycation end products and its ligands: a journey from the complications of diabetes to its pathogenesis. Ann N Y Acad Sci 1043:553-561

66. Kirschner DA, Eichberg J (1994) Restricted hypotonic swelling of peripheral nerve myelin in streptozocin-induced diabetic rats. J Neurosci Res 38:142-148
67. Kohut ML, McCann DA, Russell DW, Konopka DN, Cunnick JE, Franke WD, Castillo MC, Reighard AE, Vanderah E (2006) Aerobic exercise, but not flexibility/resistance exercise, reduces serum IL-18, CRP, and IL-6 independent of beta-blockers, BMI, and psychosocial factors in older adults. Brain Behav Immun 20:201-209

68. Koka V, Wang W, Huang XR, Kim-Mitsuyama S, Truong LD, Lan HY (2006) Advanced glycation end products activate a chymase-dependent angiotensin II-generating pathway in diabetic complications. Circulation 113:1353-1360

69. Konova E, Baydanoff S, Atanasova M, Velkova A (2004) Agerelated changes in the glycation of human aortic elastin. Exp Gerontol 39:249-254

70. Koura NH (2003) A comparison of sciatic nerve neuropathy in diabetic and aged rats. Folia Biol (Krakow) 51:213-218

71. Laufs U, Wassmann S, Czech T, Munzel T, Eisenhauer M, Bohm M, Nickenig G (2005) Physical inactivity increases oxidative stress, endothelial dysfunction, and atherosclerosis. Arterioscler Thromb Vasc Biol 25:809-814

72. Lazarevic G, Antic S, Cvetkovic T, Vlahovic P, Tasic I, Stefanovic V (2006) A physical activity programme and its effects on insulin resistance and oxidative defense in obese male patients with type 2 diabetes mellitus. Diabetes Metab 32:583590

73. Lee HJ, Park KY, Park HS, Kim IJ (2005) The effects of problem solving nursing counseling and intensified walking exercise on diabetic self-care, coping strategies, and glycemic control among clients with DM Type II. Taehan Kanho Hakhoe Chi 35:13141324

74. Li SY, Du M, Dolence EK, Fang CX, Mayer GE, Ceylan-Isik AF, LaCour KH, Yang X, Wilbert CJ, Sreejayan N, Ren J (2005) Aging induces cardiac diastolic dysfunction, oxidative stress, accumulation of advanced glycation endproducts and protein modification. Aging Cell 4:57-64

75. Lim J, Kang H, Stewart K (2004) Type 2 diabetes in Singapore: the role of exercise training for its prevention and management. Singapore Med J 45:62-68

76. Lindholm E, Bakhtadze E, Sjogren M, Cilio CM, Agardh E, Groop L, Agardh CD (2006) The -374 T/A polymorphism in the gene encoding RAGE is associated with diabetic nephropathy and retinopathy in type 1 diabetic patients. Diabetologia 49:2745-2755

77. Lindstrom J, Ilanne-Parikka P, Peltonen M, Aunola S, Eriksson JG, Hemio K, Hamalainen H, Harkonen P, Keinanen-Kiukaanniemi S, Laakso M, Louheranta A, Mannelin M, Paturi M, Sundvall J, Valle TT, Uusitupa M, Tuomilehto J (2006) Sustained reduction in the incidence of type 2 diabetes by lifestyle intervention: follow-up of the Finnish Diabetes Prevention Study. Lancet 368:1673-1679

78. Loimaala A, Huikuri HV, Koobi T, Rinne M, Nenonen A, Vuori I (2003) Exercise training improves baroreflex sensitivity in type 2 diabetes. Diabetes 52:1837-1842

79. MacDonald AL, Philp A, Harrison M, Bone AJ, Watt PW (2006) Monitoring exercise-induced changes in glycemic control in type 2 diabetes. Med Sci Sports Exerc 38:201-207

80. Machiels D, Istasse L (2002) La réaction de Maillard: importance et applications en chimie des aliments. Ann Méd Vét 146:347-352

81. Maillard L (1912) Formation dhumus et de combustibles minéraux sans intervention de l'oxygéne atmosphérique, des micro-organismes, des hautes températures ou fortes pressions. C R Acad Sci (Paris) 1912:1554-1556

82. Maiorana A, O'Driscoll G, Goodman C, Taylor R, Green D (2002) Combined aerobic and resistance exercise improves glycemic control and fitness in type 2 diabetes. Diabetes Res Clin Pract 56:115-123

83. McCance DR, Dyer DG, Dunn JA, Bailie KE, Thorpe SR, Baynes JW, Lyons TJ (1993) Maillard reaction products and 
their relation to complications in insulin-dependent diabetes mellitus. J Clin Invest 91:2470-2478

84. Meerwaldt R, Links TP, Graaff R, Hoogenberg K, Lefrandt JD, Baynes JW, Gans RO, Smit AJ (2005) Increased accumulation of skin advanced glycation end-products precedes and correlates with clinical manifestation of diabetic neuropathy. Diabetologia 48:1637-1644

85. Miele C, Riboulet A, Maitan MA, Oriente F, Romano C, Formisano P, Giudicelli J, Beguinot F, Van Obberghen E (2003) Human glycated albumin affects glucose metabolism in L6 skeletal muscle cells by impairing insulin-induced insulin receptor substrate (IRS) signaling through a protein kinase C alpha-mediated mechanism. J Biol Chem 278:47376-47387

86. Misur I, Zarkovic K, Barada A, Batelja L, Milicevic Z, Turk Z (2004) Advanced glycation endproducts in peripheral nerve in type 2 diabetes with neuropathy. Acta Diabetol 41:158-166

87. Monnier VM, Sell DR, Nagaraj RH, Miyata S, Grandhee S, Odetti P, Ibrahim SA (1992) Maillard reaction-mediated molecular damage to extracellular matrix and other tissue proteins in diabetes, aging, and uremia. Diabetes 41(Suppl 2):36-41

88. Monnier VM, Vishwanath V, Frank KE, Elmets CA, Dauchot P, Kohn RR (1986) Relation between complications of type I diabetes mellitus and collagen-linked fluorescence. $\mathrm{N}$ Engl $\mathrm{J}$ Med 314:403-408

89. Moustafa SA, Webster JE, Mattar FE (1995) Effects of aging and antioxidants on glucose transport in rat adipocytes. Gerontology 41:301-307

90. Mruthinti S, Schade RF, Harrell DU, Gulati NK, SwamyMruthinti S, Lee GP, Buccafusco JJ (2006) Autoimmunity in Alzheimer's disease as evidenced by plasma immunoreactivity against RAGE and Abeta42: complication of diabetes. Curr Alzheimer Res 3:229-235

91. Myint KM, Yamamoto Y, Doi T, Kato I, Harashima A, Yonekura $\mathrm{H}$, Watanabe T, Shinohara H, Takeuchi M, Tsuneyama K, Hashimoto N, Asano M, Takasawa S, Okamoto H, Yamamoto H (2006) RAGE control of diabetic nephropathy in a mouse model: effects of RAGE gene disruption and administration of low-molecular weight heparin. Diabetes 55:2510-2522

92. Nakamura Y, Horii Y, Nishino T, Shiiki H, Sakaguchi Y, Kagoshima T, Dohi K, Makita Z, Vlassara H, Bucala R (1993) Immunohistochemical localization of advanced glycosylation end products in coronary atheroma and cardiac tissue in diabetes mellitus. Am J Pathol 143:1649-1656

93. Niessner A, Richter B, Penka M, Steiner S, Strasser B, Ziegler S, Heeb-Elze E, Zorn G, Leitner-Heinschink A, Niessner C, Wojta J, Huber K (2006) Endurance training reduces circulating inflammatory markers in persons at risk of coronary events: impact on plaque stabilization? Atherosclerosis 186:160-165

94. Obayashi H, Nakano K, Shigeta H, Yamaguchi M, Yoshimori K, Fukui M, Fujii M, Kitagawa Y, Nakamura N, Nakamura K, Nakazawa Y, Ienaga K, Ohta M, Nishimura M, Fukui I, Kondo M (1996) Formation of crossline as a fluorescent advanced glycation end product in vitro and in vivo. Biochem Biophys Res Commun 226:37-41

95. Omsland TK, Bangstad HJ, Berg TJ, Kolset SO (2006) Advanced glycation end products and hyperglycaemia. Tidsskr Nor Laegeforen 126:155-158

96. Panteleeva IG, Rogozkin VA (2001) Effect of physical load on serum protein glycation in rats with induced diabetes. Ross Fiziol Zh Im I M Sechenova 87:1202-1207

97. Park L, Raman KG, Lee KJ, Lu Y, Ferran LJ Jr., Chow WS, Stern D, Schmidt AM (1998) Suppression of accelerated diabetic atherosclerosis by the soluble receptor for advanced glycation endproducts. Nat Med 4:1025-1031

98. Penelope AM (2005) Lack of age-related increase in average glycemia in a non-Westernized sample of rural Yucatec Maya females. Am J Phys Anthropol 126:111-121
99. Peppa M, Brem H, Ehrlich P, Zhang J-G, Cai W, Li Z, Croitoru A, Thung S, Vlassara H (2003) Adverse effects of dietary glycotoxins on wound healing in genetically diabetic mice. Diabetes 52:2805-2813

100. Peppa M, He C, Hattori M, McEvoy R, Zheng F, Vlassara H (2003) Fetal or neonatal low-glycotoxin environment prevents autoimmune diabetes in NOD mice. Diabetes 52:1441-1448

101. Perry RE, Swamy MS, Abraham EC (1987) Progressive changes in lens crystallin glycation and high-molecular-weight aggregate formation leading to cataract development in streptozotocindiabetic rats. Exp Eye Res 44:269-282

102. Radak Z, Chung HY, Naito H, Takahashi R, Jung KJ, Kim HJ, Goto S (2004) Age-associated increase in oxidative stress and nuclear factor kappaB activation are attenuated in rat liver by regular exercise. FASEB J 18:749-750

103. Rahimi K, Secknus MA, Adam M, Hayerizadeh BF, Fiedler M, Thiery J, Schuler G (2005) Correlation of exercise capacity with high-sensitive C-reactive protein in patients with stable coronary artery disease. Am Heart J 150:1282-1289

104. Ramel A, Wagner KH, Elmadfa I (2004) Correlations between plasma noradrenaline concentrations, antioxidants, and neutrophil counts after submaximal resistance exercise in men. Br J Sports Med 38:E22

105. Reddy MA, Li SL, Sahar S, Kim YS, Xu ZG, Lanting L, Natarajan R (2006) Key role of Src kinase in S100B-induced activation of the receptor for advanced glycation end products in vascular smooth muscle cells. J Biol Chem 281:13685-13693

106. Reddy S, Bichler J, Wells-Knecht KJ, Thorpe SR, Baynes JW (1995) N epsilon-(carboxymethyl)lysine is a dominant advanced glycation end product (AGE) antigen in tissue proteins. Biochemistry 34:10872-10878

107. Rett K (1999) The relation between insulin resistance and cardiovascular complications of the insulin resistance syndrome. Diabetes Obes Metab 1(Suppl 1):S8-16

108. Riboulet-Chavey A, Pierron A, Durand I, Murdaca J, Giudicelli J, Van Obberghen E (2006) Methylglyoxal impairs the insulin signaling pathways independently of the formation of intracellular reactive oxygen species. Diabetes 55:1289-1299

109. Roguin A, Nitecki S, Rubinstein I, Nevo E, Avivi A, Levy NS, Abassi ZA, Sabo E, Lache O, Frank M, Hoffman A, Levy P (2003) Vascular endothelial growth factor (VEGF) fails to improve blood flow and to promote collateralization in a diabetic mouse ischemic hindlimb model. Cardiovasc Diabetol 2:18

110. Roscic M, Horvat S (2006) Transformations of bioactive peptides in the presence of sugars - characterization and stability studies of the adducts generated via the Maillard reaction. Bioorg Med Chem 14:4933-4943

111. Rosen P, Nawroth PP, King G, Moller W, Tritschler HJ, Packer L (2001) The role of oxidative stress in the onset and progression of diabetes and its complications: a summary of a Congress Series sponsored by UNESCO-MCBN, the American Diabetes Association and the German Diabetes Society. Diabetes Metab Res Rev 17:189-212

112. Ryle C, Donaghy M (1995) Non-enzymatic glycation of peripheral nerve proteins in human diabetics. J Neurol Sci 129:62-68

113. Ryle C, Leow CK, Donaghy M (1997) Nonenzymatic glycation of peripheral and central nervous system proteins in experimental diabetes mellitus. Muscle Nerve 20:577-584

114. Sailaja Devi MM, Suresh Y, Das UN (2000) Preservation of the antioxidant status in chemically-induced diabetes mellitus by melatonin. J Pineal Res 29:108-115

115. Schmidt AM, Stern D (2000) Atherosclerosis and diabetes: the RAGE connection. Curr Atheroscler Rep 2:430-436

116. Schmidt AM, Vianna M, Gerlach M, Brett J, Ryan J, Kao J, Esposito C, Hegarty H, Hurley W, Clauss M et al (1992) 
Isolation and characterization of two binding proteins for advanced glycosylation end products from bovine lung which are present on the endothelial cell surface. J Biol Chem 267:14987-14997

117. Selam JL, Casassus P, Bruzzo F, Leroy C, Slama G (1992) Exercise is not associated with better diabetes control in type 1 and type 2 diabetic subjects. Acta Diabetol 29:11-13

118. Sevilla L, Guma A, Enrique-Tarancon G, Mora S, Munoz P, Palacin M, Testar X, Zorzano A (1997) Chronic high-fat feeding and middle-aging reduce in an additive fashion Glut4 expression in skeletal muscle and adipose tissue. Biochem Biophys Res Commun 235:89-93

119. Sigal RJ, Kenny GP, Boule NG, Wells GA, Prud'homme D, Fortier M, Reid RD, Tulloch H, Coyle D, Phillips P, Jennings A, Jaffey J (2007) Effects of aerobic training, resistance training, or both on glycemic control in type 2 diabetes: a randomized trial. Ann Intern Med 147:357-369

120. Sims TJ, Rasmussen LM, Oxlund H, Bailey AJ (1996) The role of glycation cross-links in diabetic vascular stiffening. Diabetologia 39:946-951

121. Smith MA, Taneda S, Richey PL, Miyata S, Yan S, Stern D, Sayre LM, Monnier VM, Perry G (1994) Advanced Maillard reaction end products are associated with Alzheimer disease pathology. Proc Natl Acad Sci U S A 91:5710-5714

122. Stamatas GN, Estanislao RB, Suero M, Rivera ZS, Li J, Khaiat A, Kollias N (2006) Facial skin fluorescence as a marker of the skin's response to chronic environmental insults and its dependence on age. Br J Dermatol 154:125-132

123. Steffes MW, Bilous RW, Sutherland DE, Mauer SM (1992) Cell and matrix components of the glomerular mesangium in type I diabetes. Diabetes 41:679-684

124. Stirban A, Negrean M, Stratmann B, Gawlowski T, Horstmann T, Gotting C, Kleesiek K, Mueller-Roesel M, Koschinsky T, Uribarri J, Vlassara H, Tschoepe D (2006) Benfotiamine prevents macroand microvascular endothelial dysfunction and oxidative stress following a meal rich in advanced glycation end products in individuals with type 2 diabetes. Diabetes Care 29:2064-2071

125. Stitt AW, Chakravarthy U, Archer DB, Gardiner TA (1995) Increased endocytosis in retinal vascular endothelial cells grown in high glucose medium is modulated by inhibitors of nonenzymatic glycosylation. Diabetologia 38:1271-1275

126. Stoppa GR, Cesquini M, Roman EA, Ogo SH, Torsoni MA (2006) Aminoguanidine prevented impairment of blood antioxidant system in insulin-dependent diabetic rats. Life Sci 78:1352-1361

127. Stopper H, Schinzel R, Sebekova K, Heidland A (2003) Genotoxicity of advanced glycation end products in mammalian cells. Cancer Lett 190:151-156

128. Stratton IM, Adler AI, Neil HA, Matthews DR, Manley SE, Cull CA, Hadden D, Turner RC, Holman RR (2000) Association of glycaemia with macrovascular and microvascular complications of type 2 diabetes (UKPDS 35): prospective observational study. BMJ 321:405-412

129. Suji G, Sivakami S (2004) Glucose, glycation and aging. Biogerontology 5:365-373

130. Tan KC, Shiu SW, Chow WS, Leng L, Bucala R, Betteridge DJ (2006) Association between serum levels of soluble receptor for advanced glycation end products and circulating advanced glycation end products in type 2 diabetes. Diabetologia 49:2756-2762

131. Tanji N, Markowitz GS, Fu C, Kislinger T, Taguchi A, Pischetsrieder M, Stern D, Schmidt AM, D'Agati VD (2000) Expression of advanced glycation end products and their cellular receptor RAGE in diabetic nephropathy and nondiabetic renal disease. J Am Soc Nephrol 11:1656-1666
132. Tokmakidis SP, Zois CE, Volaklis KA, Kotsa K, Touvra AM (2004) The effects of a combined strength and aerobic exercise program on glucose control and insulin action in women with type 2 diabetes. Eur J Appl Physiol 92:437-442

133. Tuomilehto J, Lindstrom J, Eriksson JG, Valle TT, Hamalainen $\mathrm{H}$, Ilanne-Parikka P, Keinanen-Kiukaanniemi S, Laakso M, Louheranta A, Rastas M, Salminen V, Uusitupa M (2001) Prevention of type 2 diabetes mellitus by changes in lifestyle among subjects with impaired glucose tolerance. N Engl J Med 344:1343-1350

134. Turk Z, Misur I, Turk N, Benko B (1999) Rat tissue collagen modified by advanced glycation: correlation with duration of diabetes and glycemic control. Clin Chem Lab Med 37:813-820

135. UKPDS (1998) Intensive blood-glucose control with sulphonylureas or insulin compared with conventional treatment and risk of complications in patients with type 2 diabetes (UKPDS 33). UK Prospective Diabetes Study (UKPDS) Group. Lancet 352:837-853

136. Unoki H, Bujo H, Yamagishi S, Takeuchi M, Imaizumi T, Saito $Y$ (2007) Advanced glycation end products attenuate cellular insulin sensitivity by increasing the generation of intracellular reactive oxygen species in adipocytes. Diabetes Res Clin Pract 76:236-244

137. Uribarri J, Peppa M, Cai W, Goldberg T, Lu M, He C, Vlassara H (2003) Restriction of dietary glycotoxins reduces excessive advanced glycation end products in renal failure patients. J Am Soc Nephrol 14:728-731

138. Valcourt U, Merle B, Gineyts E, Viguet-Carrin S, Delmas PD, Garnero P (2006) Non-enzymatic glycations of bone collagen modify osteoclastic activity and differentiation. J Biol Chem 282:5691-5703

139. van Rooijen AJ, Rheeder P, Eales CJ, Becker PJ (2004) Effect of exercise versus relaxation on haemoglobin A1C in Black females with type 2 diabetes mellitus. QJM 97:343-351

140. Vincent AM, Perrone L, Sullivan KA, Backus C, Sastry AM, Lastoskie C, Feldman EL (2006) RAGE activation injures primary sensory neurons via oxidative stress. Endocrinology 148:548-558

141. Vlassara H, Brownlee M, Cerami A (1984) Accumulation of diabetic rat peripheral nerve myelin by macrophages increases with the presence of advanced glycosylation endproducts. J Exp Med 160:197-207

142. Vlassara H, Brownlee M, Cerami A (1985) Recognition and uptake of human diabetic peripheral nerve myelin by macrophages. Diabetes 34:553-557

143. Vlassara H, Palace MR (2002) Diabetes and advanced glycation endproducts. J Intern Med 251:87-101

144. Wautier JL, Guillausseau PJ (2001) Advanced glycation end products, their receptors and diabetic angiopathy. Diabetes Metab 27:535-542

145. Wautier MP, Boulanger E, Guillausseau PJ, Massin P, Wautier JL (2004) AGEs, macrophage colony stimulating factor and vascular adhesion molecule blood levels are increased in patients with diabetic microangiopathy. Thromb Haemost 91:879-885

146. Weber F, Ziegler A (2002) Axonal neuropathy in chronic peripheral arterial occlusive disease. Muscle Nerve 26:471-476

147. Wild S, Roglic G, Green A, Sicree R, King H (2004) Global prevalence of diabetes: estimates for the year 2000 and projections for 2030. Diabetes Care 27:1047-1053

148. Yamamoto Y, Kato I, Doi T, Yonekura H, Ohashi S, Takeuchi M, Watanabe T, Yamagishi S, Sakurai S, Takasawa S, Okamoto H, Yamamoto H (2001) Development and prevention of advanced diabetic nephropathy in RAGE-overexpressing mice. J Clin Invest 108:261-268

149. Young MJ, Boulton AJ, MacLeod AF, Williams DR, Sonksen PH (1993) A multicentre study of the prevalence of diabetic 
peripheral neuropathy in the United Kingdom hospital clinic population. Diabetologia 36:150-154

150. Yu Y, Thorpe SR, Jenkins AJ, Shaw JN, Sochaski MA, McGee D, Aston CE, Orchard TJ, Silvers N, Peng YG, McKnight JA, Baynes JW, Lyons TJ (2006) Advanced glycation end-products and methionine sulphoxide in skin collagen of patients with type 1 diabetes. Diabetologia 49:2488-2498
151. Ziegler S, Schaller G, Mittermayer F, Pleiner J, Mihaly J, Niessner A, Richter B, Steiner-Boeker S, Penak M, Strasser B, Wolzt M (2006) Exercise training improves low-density lipoprotein oxidability in untrained subjects with coronary artery disease. Arch Phys Med Rehabil 87:265-269

152. Zierath JR, Wallberg-Henriksson H (1992) Exercise training in obese diabetic patients. Special considerations. Sports Med 14:171-189 